\title{
Bipartite and tripartite Cucumber mosaic virus-based vectors for producing the Acidothermus cellulolyticus endo-1,4- $\beta$-glucanase and other proteins in non-transgenic plants
}

Min Sook Hwang ${ }^{1}$, Benjamin E Lindenmuth ${ }^{2,3}$, Karen A McDonald ${ }^{2}$ and Bryce W Falk ${ }^{1 *}$

\begin{abstract}
Background: Using plant viruses to produce desirable proteins in plants allows for using non-transgenic plant hosts and if necessary, the ability to make rapid changes in the virus construct for increased or modified protein product yields. The objective of this work was the development of advanced CMV-based protein production systems to produce Acidothermus cellulolyticus endo-1, 4- $\beta$-glucanase (E1) in non-transgenic plants.

Results: We used two new Cucumber mosaic virus (CMV)-based vector systems for producing the green fluorescent protein (GFP) and more importantly, the Acidothermus cellulolyticus endo-1, 4- $\beta$-glucanase (E1) in non-transgenic Nicotiana benthamiana plants. These are the inducible CMVin (CMV-based inducible) and the autonomously replicating CMVar (CMV-based advanced replicating) systems. We modified a binary plasmid containing the complete CMV RNA 3 CDNA to facilitate insertion of desired sequences, and to give modifications of the subgenomic mRNA 4 leader sequence yielding several variants. Quantitative RT-PCR and immunoblot analysis showed good levels of CMV RNA and coat protein accumulation for some variants of both CMVin and CMVar. When genes for E1 or GFP were inserted in place of the CMV coat protein, both were produced in plants as shown by fluorescence (GFP) and immunoblot analysis. Enzymatic activity assays showed that active E1 was produced in plants with yields up to $\sim 11 \mathrm{\mu g} / \mathrm{g}$ fresh weight (FW) for specific variant constructs. We also compared in vitro CMV genomic RNA reassortants, and CMV RNA 3 mutants which lacked the $C^{\prime}$ terminal 33 amino acids of the $3 \mathrm{~A}$ movement protein in attempts to further increase E1 yield. Taken together specific variant constructs yielded up to $\sim 21 \mu \mathrm{g} / \mathrm{g}$ FW of E1 in non-transgenic plants.

Conclusions: Intact, active E1 was rapidly produced in non-transgenic plants by using agroinfiltration with the CMV-based systems. This reduces the time and cost compared to that required to generate transgenic plants and still gives the comparable yields of active E1. Our modifications described here, including manipulating cloning sites for foreign gene introduction, enhance the ease of use. Also, N. benthamiana, which is particularly suitable for agroinfiltration, is a very good plant for transient protein production.
\end{abstract}

Keywords: Cucumber mosaic virus, Protein production, Endoglucanase, Agrobacterium tumefaciences, Viral vector, Transient protein expression, Nicotiana benthamiana

\footnotetext{
*Correspondence: bwfalk@ucdavis.edu

'Department of Plant Pathology, University of California, One Shields Avenue, Davis, CA 95616, USA

Full list of author information is available at the end of the article
} 


\section{Background}

Using plant viruses as vehicles for foreign protein production in plants offers many advantages over more traditional prokaryotic-based, and even over transgenic plant-based protein production systems. For example, plants are relatively easy and inexpensive to grow, plants are able to perform post-translational protein modifications (e.g. glycosylation) not possible with prokaryotes, and plant cells can secrete appropriately engineered proteins allowing for simplified product purification $[1,2]$. Transgenic plants engineered to produce desirable proteins offer some of these advantages, but engineered plants require substantial time, effort and cost to develop and do not offer flexibility for rapid change if modifications to the protein product are desired. By contrast, using plant viruses to produce desired proteins in plants allows for using non-transgenic plant hosts and if necessary, the ability to make rapid changes in the virus construct for increased or modified protein product yields.

Cucumber mosaic virus (CMV) is the one of the viruses that has been used for protein production in plants $[3,4]$. CMV has an extremely wide plant host range [5] which opens the door for using plants other than only Nicotiana spp. for producing proteins, and thus an optimized CMV-based protein production system would be very desirable. But CMV also has some potential drawbacks for foreign protein production. CMV has a tripartite single-stranded RNA genome and each genomic RNA is packaged separately within icosahedral capsids [5]. CMV genomic RNAs 1 and 2 encode the $1 \mathrm{a}$ and $2 \mathrm{a}$ proteins, respectively, which are involved in viral RNA replication [5,6]. RNA 2 also encodes a small protein called $2 \mathrm{~b}$, which affects virulence and is known to suppress the initiation of the plant defense, RNA silencing, and to play a role in promoting cellto-cell movement [7]. RNA 3 also is bicistronic, encoding the cell-to-cell movement protein (MP) and the virion capsid protein $(\mathrm{CP})$. All three CMV genomic RNAs are essential for the systemic plant infection and all five CMV-encoded proteins directly or indirectly affect the movement of CMV within the plant host [5]. Still, CMV genome segments 2 and 3 have been modified in some cases for insertion of specific sequences which can give foreign protein production in plants $[4,8,9]$.

In our previous work we engineered a binary plasmid to contain modified complementary DNAs (cDNAs) representing the complete CMV tripartite genome, in which the CMV coat protein gene was replaced by the gene encoding $\alpha-1$-antitrypsin [AAT] [9]. We deleted a region of the CMV RNA 1 leader sequence to ensure that the viral replicase was not able to replicate the truncated RNA 1 and since coat protein was lacking, infectious CMV was not generated thereby eliminating possible unwanted spread of the recombinant CMV. Furthermore, because one of the key CMV-encoded protein components of the viral replicase (1a) is under the control of a relatively tightly regulated chemically inducible promoter (the XVE inducible promoter [10]), recombinant viral amplicons were produced intracellularly only after addition of the inducer ( $\beta$-estradiol). The high efficiency and specificity are among the major advantages of the XVE system, and thus it provides a potent tool for research in plant biotechnology.

Despite the advantage of having all CMV components on a single plasmid (e.g. ensuring that all CMV components are simultaneously introduced into the same cell) [9], the CMViva plasmid proved to not be easy for subsequent manipulation. Its size alone $(28 \mathrm{kbp})$ made subsequent cloning manipulations difficult. Therefore, here we explored development of new CMV-based smaller-sized variants by separating genome components onto different plasmids to give a bipartite inducible (CMVin, CMV-based inducible system) and tripartite, autonomously replicating forms of CMV (CMVar, CMVbased advanced replicating system). We also assessed the effects of mRNA4 leader sequence variants and compared two CMV genotypes for their abilities to give in planta production of two proteins, the green fluorescent protein (GFP) and the Acidothermus cellulolyticus endo$1,4-\beta$-glucanase (E1), a cellulose degrading enzyme. This heat-stable, 56,000 MW well-studied endoglucanase has been produced previously in different species of transgenic plants [11-13], and is believed to have potential application for cellulose biomass conversion to sugars and use in biofuel production. Here we show that active E1 can be rapidly produced in non-transgenic plants by using agroinfiltration with the CMV-based systems. This reduces the time and energy required to generate transgenic plants and still gives the comparable yields of active E1 to those obtained previously by others.

\section{Methods}

\section{Plants and photography}

Three-week-old Nicotiana benthamiana plants and nine day old zucchini squash (Cucurbita pepo L. cv. Green Bush) plants were used for virus inoculations or agroinfiltration. Plants were photographed with a Cannon G6 digital camera equipped with a Tiffen Deep Yellow 15 filter. For photographing GFP expression, plants were illuminated with a hand-held long-wave UV lamp.

\section{Cloning and plasmid construction}

In order to develop CMVin (CMV-based inducible system) and CMVar (CMV-based advanced replicating system), the gene-of-interest was inserted into the coat protein coding region of CMV-Q RNA 3 (GenBank: M21464) [14] to give pCMVar RNA 3. We modified the 
CMV RNA 3 intergenic region, which also gives rise to the mRNA 4 leader sequence, by PCR primer tagging to introduce additional restriction enzyme sites for easier cloning. This was done by PCR amplifying the CP coding region using tagged forward primers (EATG for sequence 2, HATG for sequence 6, PHATG for sequence 8 , and CPfwd for the wild type leader sequence, Table 1) and the reverse primer (CPrev listed in Table 1), and GoFlexi Taq DNA polymerase (Promega Corp., Madison, WI, U.S.A.). Amplified fragments were transferred to pGEM-T Easy (Promega Corp., Madison, WI, U.S.A.)

Table 1 List of primers used here

\begin{tabular}{|c|c|}
\hline Primer ID & Sequences $5^{\prime}-3^{\prime}$ \\
\hline realRna3onlyfwd & AACAGATTAGCCGAGCATTCG \\
\hline realRrna3rev & AGCTAACGTTGTTTAACTGCGACTT \\
\hline realRna4onlyfwd & AGTGCCTTCATCATCCGATCTT \\
\hline realRna4onlyrev & GGTGAGTTACCATCGCCAAAC \\
\hline real18Sfwd & TACGCCCCGCCCAAA \\
\hline real18Srev & CACTGGCAGTCCTTCGTGAGT \\
\hline RNA3end & TGGTCTCCTTATGGAGAACCTGTGG \\
\hline realRnalfwd & TGGTCAGTATGCCCCAAAGG \\
\hline realRna1rev & TTCAAGGGTAGCTCGACAACCT \\
\hline realRna2fwd & CCCAGACTGATGTCTCCCAAA \\
\hline realRna2rev & GAGTGTTGCCCTGGTTCGAA \\
\hline GFPfwd & ATGGCTAGCAAAGGAGAAGA \\
\hline GFPrev & TTATTTGTAGAGCTCATCCA \\
\hline Rna4wtrev & AGGCACACTGAGACGCAAAA \\
\hline Rna42rev & GAATTCTCTCAGAATCACTA \\
\hline Rna46rev & AAGCTTTCTCAGAATCACTA \\
\hline Rna48rev & AAGCTTCTGCAGAATTCGCC \\
\hline CPfwd & ATGGACAAATCTGGATCTCCCAAT \\
\hline CPrev & CTAAGTCGGGAGCATCCGTGAGAT \\
\hline EATG & CTGAGAGAATTCATGGACAAATCTGGATCTCCCAAT \\
\hline HATG & CTGAGAAAGCTTATGGACAAATCTGGATCTCCCAAT \\
\hline PHATG & GAGACTGCAGAAGCTTATGGACAAATCTGGATCTCCC \\
\hline RNA1fwd & GTTTATTTACAAGAGCGTA \\
\hline RNA12rev & TGGTCTCCTIITGGAGGCC \\
\hline RNA2fwd & GTTTATTCTCAAGAGCGTA \\
\hline IRNA12fwd & GTTATTTACAAGAGCGTACGGTT \\
\hline IRNA12rev & TGGTCTCTITIAGAGGCCCCCACG \\
\hline downstreamfwd & TCCGTGTGTTTACCGGCGTCCGAA \\
\hline endoonlyfwd & ATGAAGAATACATCCTCCTT \\
\hline endoonlyrev & TCAGTGGTGATGGTGATGATGGGA \\
\hline 35SPfwd & GTCAACATGGTGGAGCACGA \\
\hline 35STrev & GATTTAGTACTGGAT \\
\hline 35SPrev & CСTCTCCAAATGAAATGAAC \\
\hline 35STfwd & ATTCGGTACGCTGAAATCAC \\
\hline 33delfwd & TAGTGTITTGTTACGTTGTACCT \\
\hline 33delrev & CCCAGACGCATTTTGATTAAGAG \\
\hline
\end{tabular}

and sequences were verified. Plasmids were then digested by Pst I and Tth111 I, and the desired fragment was transferred to pQA3 [9] (Additional file 1: Figure S1). Then sequences containing the CaMV 35S (35S) promoter, RNA 3 and $35 \mathrm{~S}$ terminator were PCR amplified using primers 35SPfwd and 35STrev (Table 1) and Pfu DNA polymerase (Stratagene, Agilent TechnologiesCompany, U.S.A), and the resulting fragments were ligated into the Sma I site of the mini binary vector, pCB301 [15] (Additional file 1: Figure S1). These were then used as the RNA 3 source for CMVar and CMVin variants. The higher producing constructs (containing the 2, 6, and 8 modified, and wildtype leader sequences of RNA4; Additional file 2: Figure S2) were selected for further experiments.

The E1 sequence (GenBank:HQ541433) used here was first codon-optimized for dicots and constructed to contain the rice alpha amylase (RAmy 3D, GeneBank: M59351) signal peptide at its N'-terminus, and a 6-His tag at its C' terminus (synthesized by DNA2.0, Menlo Park, CA, http://www.dna20.com, and provided as plasmid DNA pJL201:11772) ([16], see Figure 1A). The green fluorescent protein (GFP) and E1 coding sequences were PCR amplified and cloned into the CP coding region of pCMVar RNA 3.

First, primer sets downstreamfwd and the Rna4wtrev, Rna42rev, Rna46rev, Rna48rev (listed in Table 1), were used for reverse PCR to remove the $\mathrm{CP}$ coding region (Additional file 3: Figure S3). The E1 gene was amplified by PCR using specific primers set (endoonlyfwd and endoonlyrev as listed in Table 1) and ligated into coat protein gene-deleted pCMVar RNA 3 by blunt end ligation (Additional file 3: Figure S3), yielding pCMVar E. The GFP coding sequence was PCR amplified from pCMViva GFP [9] using the specific primer sets (GFPfwd and GFPrev listed in Table 1), and cloned into the coat protein region of pCMVar RNA 3 using the same methods as for E1, resulting in pCMVar G (Additional file 3: Figure S3).

To generate the CMVar replicating constructs, CMV RNA 1 and RNA 2 segments (for CMV subgroup I and II) were PCR amplified using the specific forward and reverse primer sets (RNA1fwd and RNA12rev for subgroup II RNA 1, RNA2fwd and RNA12rev for subgroup II RNA 2, IRNA1fwd and IRNA12rev for subgroup I RNA 1, IRNA2fwd and IRNA12rev for subgroup II RNA 2 , respectively, as listed in Table 1). The RNA 3 region of pCMVar RNA 3 was removed and replaced by the RNA 1 or 2 genome segments and gave I and II pCMVar RNA 1 and 2 (Additional file 4: Figure S4). The subgroup I RNA 1 and RNA 2 were originally from a California CMV [17], and the subgroup II RNA 1 and RNA 2 were from CMV-Q (GenBank:X02733 for RNA 1, X00985 for RNA 2, respectively). 


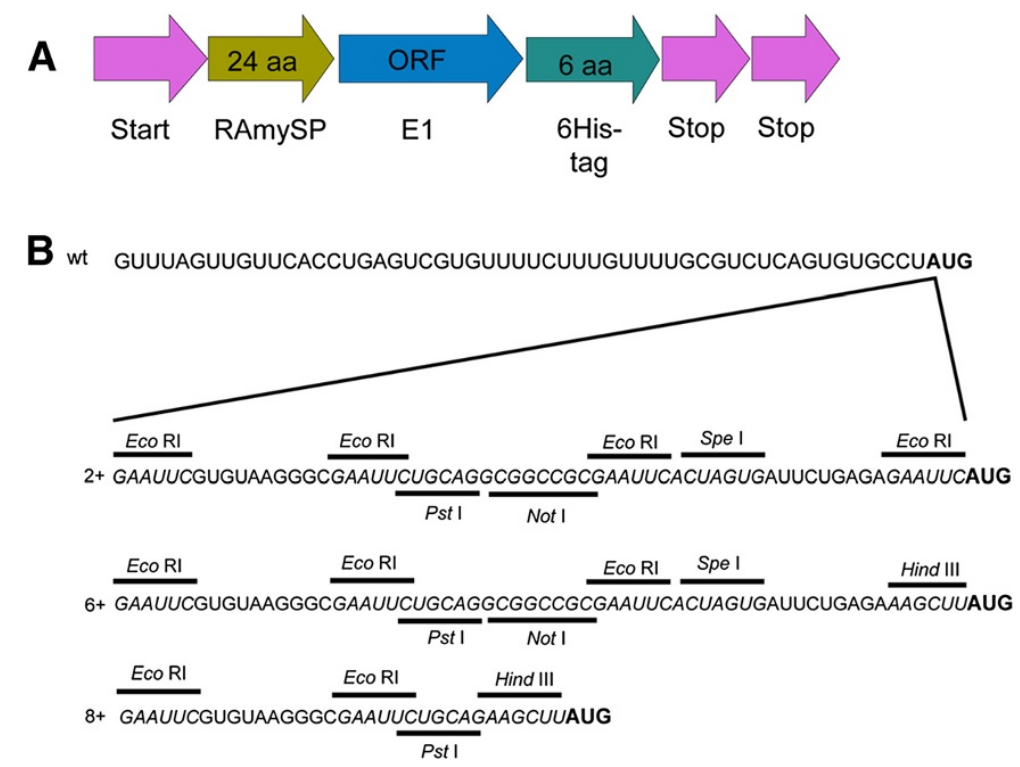

Figure 1 (A) Diagram of the E1 constructs and (B) Modified RNA 4 leader sequences containing restriction enzyme sites compared to unmodified wild type (wt) leader sequences. (A) Gene structure of the E1 used in this report. The E1 gene contains the rice amylase signal peptide in the upstream of its ORF and a 6 histidine-tag in its C-terminus. RAmySP; rice amylase signal sequence. This Figure is not to scale. (B) Restriction endonuclease sequences are shown as italicized and underlined, the CP start codon (AUG) is shown in bold. Modified leader sequences are located between the wildtype leader sequence and AUG start codon in subgenomic RNA4. Wt, wildtype leader sequence; $2+$, modified \#2 leader sequences addition to the wildtype leader sequence; $6+$, modified \#6 leader sequences addition to the wildtype leader sequence; $8+$, modified \#8 leader sequences addition to the wildtype leader sequence.

For the CMVin system, RNA 1 and 2 segments came from pDUXLR1R2 (pR1R2; [9] which includes the modified RNA 1 sequence. The monopartite inducible CMViva expression system, pCMV containing all three CMV genomic RNA segments in a single plasmid was used as control [9]. The plasmid, pCassQ123, containing all three CMV RNA segments in a single plasmid and each driven by the $35 \mathrm{~S}$ promoter was a gift from Dr. ShouWei Ding, UC Riverside.

In order to construct the CMV MP 33 amino acid deletion mutants, we used PCR and the specific primer set (33delfwd and 33delrev, listed in Table 1). PCR products were eluted from an agarose gel and self ligated to make pCMVar 33 G 2, 6, 8, wt and pCMVar 33E 2, 6, 8, wt variants, respectively (Additional file 5: Figure S5). Table 2 shows the names, activities and genotypes for the expression system variants used in this paper.

\section{Agroinfiltration}

Binary plasmids purified from E. coli cultures were transformed into Agrobacterium tumefaciens GV3101 or EHA105 cells using electroporation. Transformed $A$. tumefaciens cells were plated on Luria-Bertani plates containing Rifampicin $(10 \mu \mathrm{g} / \mathrm{ml})$ and Gentamycin (20 $\mu \mathrm{g} / \mathrm{ml})$ for GV3101 and Kanamycin $(50 \mu \mathrm{g} / \mathrm{ml})$ for specific constructs, and Rifampicin $(10 \mu \mathrm{g} / \mathrm{ml})$ and Tetracycline $(10 \mu \mathrm{g} / \mathrm{ml})$ for EHA105 and Gentamycin $(20 \mu \mathrm{g} / \mathrm{ml})$ for specific constructs, respectively. For agroinfiltration, a single colony was inoculated into $5 \mathrm{ml}$ L-MESA media (100 ml LB broth, $2 \mathrm{ml} 0.5 \mathrm{M} \mathrm{MES} \mathrm{(pH} \mathrm{5.7),} 20 \mu \mathrm{l} 0.1 \mathrm{M}$ acetosyringone) and grown to an $\mathrm{OD}_{600}$ of 1.0. Cells were harvested by centrifuging for $10 \mathrm{~min}$ at $3,500 \mathrm{~g}$ and resuspended in induction media $\left(50 \mathrm{ml}\right.$ sterile $\mathrm{dH}_{2} \mathrm{O}, 0.5 \mathrm{ml} 1 \mathrm{M}$ $\mathrm{MgCl}_{2}, 1 \mathrm{ml} 1 \mathrm{M}$ MES (pH 5.7), $50 \mu \mathrm{l} 0.1 \mathrm{M}$ Acetosyringone), and allowed to sit at room temperature for $3 \mathrm{hrs}$ before infiltration. When mixtures of A. tumefaciens cells were infiltrated into plants, cultures were prepared separately in induction medium and combined immediately before infiltration. For inoculating small sugar pumpkin plants, $A$. tumefaciens cells containing the constructs were infiltrated into $N$. benthamiana plants. Leaves were harvested 6 days after infiltration, and used for standard rub inoculation.

\section{RNA extraction and realtime RT-PCR}

Samples for RNA and protein extraction were harvested from infiltrated and non-infiltrated leaves at 6 days after infiltration. Total RNA was extracted using the RNeasy kit (QIAGEN Inc., U.S.A.) following the manufacturer's instructions. Complementary DNA (cDNA) synthesized from DNase-digested total RNA was used for reverse transcription using the RNA 3end primer as listed in Table 1 and SuperScript II Reverse Transcriptase, as described by the manufacturer (Invitrogen, Carlsbad, 
Table 2 Nomenclature and composition of CMV-based systems

\begin{tabular}{|c|c|c|c|c|}
\hline $\begin{array}{l}\text { Leader } \\
\text { sequences } \\
\text { in mRNA4 }\end{array}$ & $\begin{array}{c}\text { Protein } \\
\text { encoded } \\
\text { by RNA3 }{ }^{1}\end{array}$ & $\begin{array}{c}\text { Genotype } \\
\text { of RNA } \\
1 \text { and } 2^{2}\end{array}$ & $\begin{array}{l}\text { Replicating } \\
\text { (R) or } \\
\text { inducible(I) }\end{array}$ & $\begin{array}{c}\text { Name of } \\
\text { combined } \\
\text { CMV variants }\end{array}$ \\
\hline wt & $C P$ & Subgroup I & $\mathrm{R}$ & CMVarl wt \\
\hline 2 & & & & CMVarl 2 \\
\hline 6 & & & & CMVarl 6 \\
\hline 8 & & & & CMVarl 8 \\
\hline wt & $C P$ & Subgroup II & $\mathrm{R}$ & CMVarll wt \\
\hline 2 & & & & CMVarll 2 \\
\hline 6 & & & & CMVarll 6 \\
\hline 8 & & & & CMVarll 8 \\
\hline wt & $C P$ & Subgroup II & I & CMVinll wt \\
\hline 2 & & & & CMVinll 2 \\
\hline 6 & & & & CMVinll 6 \\
\hline 8 & & & & CMVinll 8 \\
\hline wt & GFP & Subgroup I & $\mathrm{R}$ & CMVarl Gwt \\
\hline 2 & & & & CMVarl G2 \\
\hline 6 & & & & CMVarl G6 \\
\hline 8 & & & & CMVarl G8 \\
\hline wt & GFP & Subgroup II & $\mathrm{R}$ & CMVarll Gwt \\
\hline 2 & & & & CMVarll G2 \\
\hline 6 & & & & CMVarll G6 \\
\hline 8 & & & & CMVarll G8 \\
\hline wt & GFP & Subgroup II & 1 & CMVinll Gwt \\
\hline 2 & & & & CMVinll G2 \\
\hline 6 & & & & CMVinll G6 \\
\hline 8 & & & & CMVinll G8 \\
\hline wt & E1 & Subgroup I & $\mathrm{R}$ & CMVarl Ewt \\
\hline 2 & & & & CMVarl E2 \\
\hline 6 & & & & CMVarl E6 \\
\hline 8 & & & & CMVarl E8 \\
\hline wt & E1 & Subgroup II & $\mathrm{R}$ & CMVarll Ewt \\
\hline 2 & & & & CMVarll E2 \\
\hline 6 & & & & CMVarll E6 \\
\hline 8 & & & & CMVarll E8 \\
\hline wt & E1 & Subgroup II & I & CMVinll Ewt \\
\hline 2 & & & & CMVinll E2 \\
\hline 6 & & & & CMVinll E6 \\
\hline 8 & & & & CMVinll E8 \\
\hline wt & GFP & Subgroup I & $\mathrm{R}$ & CMVarl 33Gwt \\
\hline 2 & & & & CMVarl 33 G2 \\
\hline 6 & & & & CMVarl 33 G6 \\
\hline 8 & & & & CMVarl 33 G8 \\
\hline wt & GFP & Subgroup II & $\mathrm{R}$ & CMVarll 33GWt \\
\hline 2 & & & & CMVarll 33 G2 \\
\hline 6 & & & & CMVarll 33 G6 \\
\hline 8 & & & & CMVarll 33 G8 \\
\hline
\end{tabular}

Table 2 Nomenclature and composition of CMV-based systems (Continued)

\begin{tabular}{|c|c|c|c|c|}
\hline wt & GFP & Subgroup II & I & CMVinll 33Gwt \\
\hline 2 & & & & CMVinll 33 G2 \\
\hline 6 & & & & CMVin\| 33 G6 \\
\hline 8 & & & & CMVinll 33 G8 \\
\hline wt & E1 & Subgroup I & $\mathrm{R}$ & CMVarl 33Ewt \\
\hline 2 & & & & CMVarl 33E2 \\
\hline 6 & & & & CMVarl 33E6 \\
\hline 8 & & & & CMVarl 33E8 \\
\hline wt & E1 & Subgroup II & $\mathrm{R}$ & CMVarll 33Ewt \\
\hline 2 & & & & CMVarll 33E2 \\
\hline 6 & & & & CMVarll 33E6 \\
\hline 8 & & & & CMVarll 33E8 \\
\hline wt & E1 & Subgroup II & 1 & CMVinll 33Ewt \\
\hline 2 & & & & CMVinll 33E2 \\
\hline 6 & & & & CMVinll 33E6 \\
\hline 8 & & & & CMVinll 33E8 \\
\hline
\end{tabular}

${ }^{1}$ All RNA3 constructs are from subgroup II CMV-Q. ${ }^{2}$ RNA 1 and 2 sources are subgroup I or subgroup II as indicated. Cells containing required plasmids were mixed and infiltrated into non-transgenic $N$. benthamiana plants as described.

CA, U.S.A.). Realtime PCR was performed using gene specific primers for each CMV RNA segment (realrna1fwd and realrna1rev for RNA 1, realrna2fwd and realrna2rev for RNA 2, realrna3onlyfwd and realrna3onlyrev for RNA 3, realrna4onlyfwd and realrna4onlyrev for RNA 4, and real18Sfwd, real18Srev for endogenous $18 \mathrm{~S}$ control, respectively as listed in Table 1). Real-time PCR was performed using SYBR Green PCR master mix (Applied Biosystems, Life Technologies Corporation, Carlsbad, CA, U.S.A.) in an ABI Prism 7500 Sequence Detection system (Applied Biosystems, Life Technologies Corporation, Carlsbad, CA, U.S.A.) under standard amplification conditions $\left(95^{\circ} \mathrm{C}\right.$ for $5 \mathrm{~min}$, followed by 40 cycles of $95^{\circ} \mathrm{C}$ for $15 \mathrm{~s}$ and $60^{\circ} \mathrm{C}$ for $1 \mathrm{~min}$ ). The threshold cycle $\left(C_{\mathrm{T}}\right)$ is defined as the fractional cycle number at which the fluorescence exceeded the fixed threshold. Statistical analyses were performed using the Bonferroni (Dunn) $t$ test using the SAS 9.1 program.

\section{Protein extraction and immunoblotting}

Proteins were extracted from leaves using protein extraction buffer (100 mM Tris- $\mathrm{HCl}(\mathrm{pH} 8.0), 10 \mathrm{mM}$ EDTA, $5 \mathrm{mM}$ DTT, $150 \mathrm{mM} \mathrm{NaCl}, 0.1 \%$ Triton X-100, $1 \mathrm{X}$ protease inhibitor (Roche diagnostics, Germany) and tissue maceration using a bead-beater. Samples were centrifuged at 12,000 $\mathrm{g}$ for $20 \mathrm{~min}$ to remove cell debris, and protein concentrations were determined by Bradford assay using Coomassie Plus (Pierce, Thermo Scientific, IL, U.S.A.) with bovine serum albumin as the standard. Proteins were analyzed by SDS-PAGE in $12 \%$ 
polyacrylamide gels and transferred to Hybond-C Extra membranes (Amersham Pharmacia Biotech, U.K.). Membranes were incubated with rabbit CMV anti-CP polyclonal antibody at 1:2,500 dilution, followed by goat anti-rabbit IgG-alkaline phosphatase conjugate (Bio-Rad, Hercules, CA, U.S.A.) at 1:2,500 dilution. For E1 detection, membranes were incubated with specific mouse monoclonal IgG anti-E1 antibody (provided by Bill Adney, National Renewable Energy Lab) at 1:2,500 dilution, followed by goat anti-mouse IgG alkaline phosphatase conjugate (Bio-Rad, Hercules, CA, U.S.A.) at 1:2,500 dilution. After washing with Tris-buffered saline (100 mM Tris-Cl, pH 7.5, 0.9\% $\mathrm{NaCl}$ ) with $0.3 \%$ Tween20 for three times, the membrane was developed to a purple color using colorimetric AP conjugate substrate reagent kit (Bio-Rad, Hercules, CA, U.S.A.) including premixed BCIP (5-bromo-4-chloro-3-indolyl phosphate) and NBT (nitroblue tetrazolium) substrate solutions (Bio-Rad, Hercules, CA, U.S.A.).

\section{Endoglucanase (E1) activity assays}

Endoglucanase (E1) activity assays were done as described [16]. A $60 \mu \mathrm{l}$ aliquot of diluted supernatant containing E1 was added to $540 \mu \mathrm{l}$ of acetate buffer (200 mM acetate, pH 5.5, $100 \mathrm{mM} \mathrm{NaCl}$ ) and $200 \mu \mathrm{l}$ of substrate $(500 \mu \mathrm{M}$ methylumbelliferyl-tagged cellobiose (MUC)). Then, $200 \mu \mathrm{l}$ of the reaction was sampled at time zero and after $30 \mathrm{~min}$, and added to $800 \mu \mathrm{l}$ of stop buffer (150 mM glycine, $\mathrm{pH} 10)$. The change in fluorescence as released methylumbelliferine (MU) over time was measured with a VersaFluor fluorometer (Bio-Rad, Hercules, CA, U.S.A.). Fluorescence was converted to activity, and specific activity was determined as described [16].

\section{Results \\ Modified RNA4 leader sequences affect mRNA and coat protein levels}

To facilitate cloning desired genes into the CMV CP region, we first created a separate CMV RNA 3-based plasmid and modified the intergenic nucleotide sequence upstream of the CP ORF start codon to contain desired restriction endonuclease sites (Figure 1). This also resulted in changes to the mRNA 4 nucleotide leader sequence immediately preceding the AUG start codon and therefore could affect mRNA translation efficiency [1820]. Therefore, we first compared the respective CMVin and CMVar variants for their ability to replicate and to express CMV CP within infiltrated leaves. We used realtime PCR to quantify levels of progeny RNAs 1, 2, 3, and 3 plus 4 (because RNA 4 is a subset of RNA 3 and is therefore difficult to differentiate from RNA 3).

When we compared the CMVinII variants with CMViva, all showed accumulation of genomic and subgenomic RNAs, and of CMV CP (Figure 2A). Because we are most interested in protein production from RNA 4, comparison of the RNA 3 \& 4 data show that the modified variants (CMVinII 2, 6 and 8) all showed slightly more RNAs 3 and 4 than did the wildtype CMVinII, but none were higher than CMViva (Figure 2A). Although the levels of RNAs 3 and 4 were not statistically different, comparison of CMV CP accumulation showed more CMV CP was detected for CMVinII variants 2, 6, 8 and CMViva, than was for the wildtype CMVinII. CMViva and CMVinII variants both have 46 nucleotide deletions in the inducible CMV RNA 1 such that although it is transcribed and the resulting RNA 1 serves for translation to yield the 1a protein, the RNA 1 genome segment is not replicated as are genome segments RNAs 2 and 3 (Additional file 2: Figure S2). Because the 1a component of the replicase complex is under the control of a relatively tightly regulated chemically inducible promoter, the recombinant viral amplicons are only produced under induction conditions.

When we compared the CMVarII variants, all showed accumulation of all CMV RNAs, and so long as inocula contained all three CMV genomic RNAs, accumulation of RNAs 1, 2 and 3 was not significantly different for the different variants. However, realtime PCR analysis showed lower accumulation of RNAs $3+4$ for CMVarII variant6 when compared to the monopartite pQ123 (Figure 2B). All CMVarII variants showed much less CP accumulation than was seen for pQ123, and CMVarII 2, 6 and 8 showed less $\mathrm{CP}$ than did CMVarII wt (Figure 2B). However, all CMVarII variants were able to initiate systemic infections in $N$. benthamiana and zucchini squash plants (Additional file 6: Figure S6). RTPCR and nucleotide sequence analysis of the CMV progeny showed that the modified leader sequences were retained in RNAs extracted from systemically-infected leaves (data not shown).

\section{CMVinll and CMVarll variants yield high GFP fluorescence}

To assess foreign protein production we first cloned the gene for GFP into the CP coding region for the CMVinII and CMVarII variants. Non-transgenic N. benthamiana plants were infiltrated and leaves were examined for fluorescence at 6 and 10 days post-infiltration. At 6 days post-infiltration bright GFP fluorescence was seen in the infiltrated regions (Figure 3). In general, the regions of the leaves infiltrated with CMVinII and CMVarII variants showed very bright fluorescence. By 10 days postinfiltration, bright GFP fluorescence was observed for the CMVinII and CMVarII variants, regardless of leader sequence. Despite the fact that CMVarII variants producing the CMV CP spread within plants giving systemic infections, CMVarII variants producing GFP did not, and fluorescence was localized to the infiltrated areas. 


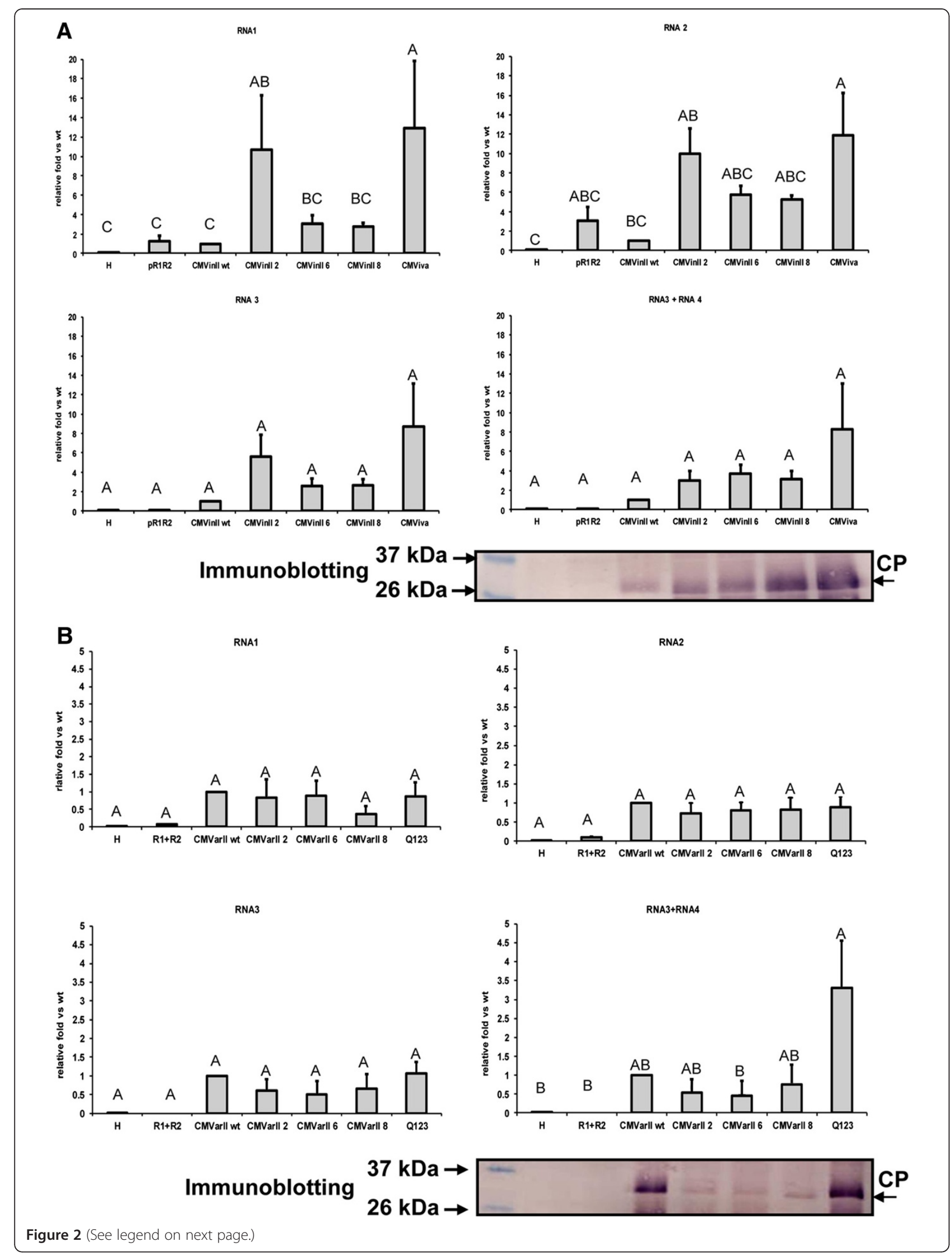


(See figure on previous page.)

Figure 2 Relative RNA and coat protein accumulation levels for CMVinll and CMVarll variants having wt or modified RNA 4 leader sequences. After 6 days post-infiltration, infiltrated leaves were harvested and total RNAs and proteins were extracted as described in Methods. For CMVinll variants (see Table 2), estradiol was applied 18 hrs after infiltration using a cotton swab. For CMVinll variants, two leaves each from 3 plants for each treatment $(n=6)$ were used for $1^{\text {st }}, 2^{\text {nd }}$ biological trials, and three leaves each from 2 plants for $3^{\text {rd }}, 4^{\text {th }}$ trials $(n=6)$ yielding four different biological trials (total $n=24$ ). For CMVarll variants (see Table 2), two leaves each from 3 plants for each treatment $(n=6)$ were used for analysis. These experiments were replicated three times (total $n=18$ ). For immunoblot analysis, each lane was loaded with $15 \mu \mathrm{g}$ of total protein. Real-time PCR reactions were performed using an ABI 7500 with gene specific primer sets. Relative Ct values were calculated to the respective $18 \mathrm{~S}$ rRNA relative concentration. Relative folds were calculated to the repective wildtype CMVinll and CMVarll value, respectively. Group superscript letters next to the numbers represent different statistical groups, means with the same letter are not significantly different by the Bonferroni (Dunn) t test using the SAS 9.1 program. Panel (A) CMVinll variants; $\mathrm{H}$, healthy uninfiltrated leaf; pR1R2, pCMVinll RNA 1 and RNA 2 only; CMVinll wt, wt leader; CMVinll 2, \#2 leader; CMVinll 6, \#6 leader; CMVinll 8, \#8 leader; CMViva, pCMV (see Methods). Panel (B) CMVarll variants; $\mathrm{H}$, healthy, uninfiltrated leaf; R1 + R2, pCMVarll RNA 1 and RNA 2 only; CMVarll wt, wild type leader; CMVarll 2 , \#2 leader; CMVarll 6 , \#6 leader; CMVarll 8, \#8 leader; pQ123, pCassQ123 (see Methods).

This is most likely because these variants do not produce CMV CP, which is known to be a determinant of CMV systemic spread in plants [21,22], and thus these infections were localized to the infiltrated regions of the treated leaves. We also tested another reporter protein, the red fluorescent protein (RFP), for expression using CMVinII and CMVarII and obtained essentially identical results to those shown for the variants expressing GFP (data not shown).

\section{E1 was produced in plants using both CMVinll and CMVarll variants}

Our intent is to develop easy-to-use CMV variants that give efficient production of desirable proteins in nontransgenic plants, including proteins with potential biofuel applications. Therefore, we next assessed E1 accumulation in leaves of infiltrated $N$. benthamiana plants. We first used immunoblot analysis to detect total E1 accumulation in leaves infiltrated with the CMVinII and CMVarII variants. E1 was detected in the infiltrated leaves for both CMVinII and CMVarII wild type variants (Figure 4). The leader sequence $C M V i n I I$ variants 6 and 8 showed higher E1 compared to the wildtype CMVinII. For CMVarII variants, the wild type showed higher E1 accumulation, but the 6 and 8 variants also gave good E1 accumulation (Figure 4). Interestingly, the intact E1 migrated as a ca. $72 \mathrm{KDa}$ protein as shown in Figure 4 and Additional file 7: Figure S7, even though the calculated MW of E1 is $57.3 \mathrm{KDa}$, including the histidine tag and rice amylase signal peptide (See Figure 1A). Similar reports for anomalous E1 migration in SDS-PAGE have been previously reported $[16,23]$.

The immunoblot experiments showed E1 protein accumulation but our interest is in production of enzymatically active E1. Therefore we used activity assays on plant extracts to estimate yields of active E1. In repeated experiments, the CMVinII E6 and E8 consistently yielded 8 to almost 15 fold higher relative E1 accumulation than wildtype CMVinII E, while the yield for CMVi$n$ II E2 was negligible. By contrast, the wildtype CMVarII
E consistently yielded more E1 than the other CMVarII variants (Table 3). CMVarII E2 gave negligible E1 accumulation while CMVarII E6 and E8 showed low yields, but much less than wildtype CMVarII E. We had anticipated that CMVarII would give higher protein accumulation in plants because of RNA 1 replication, which is lacking in CMVinII (Additional file 2: Figure S2), but this proved not to be the case, the highest overall yields were obtained with CMVinII E 6 and 8. The CMVarII is easier to use since there is no requirement for adding the RNA 1 inducer, estradiol, and if we could achieve higher protein accumulation with CMVarII this would be our choice. Therefore we next attempted to increase CMVar-driven protein accumulation by two additional approaches: to increase CMV RNA replication and to increase CMV spread within plants.

\section{Reassortant CMVarl variants yield more protein compared to CMVarll variants}

CMV is one of the world's most widespread plant viruses, and has many genetic variants which are primarily divided into the taxonomic subgroups I and II [5]. In general, subgroup I CMVs show more severe symptoms in plants than do subgroup II CMV isolates, which can show mild or even symptomless infections. This is suggested to be associated with the $2 \mathrm{~b}$ protein (encoded by RNA 2) as a silencing suppressor [24], and effects can vary in different plant hosts [25]. Therefore, we generated and compared CMV subgroup I and II genomic reassortants for their abilities to give greater replication and protein production. All reassortants contained the same CMV subgroup II wildtype RNA 3 or variant constructs for GFP or E1. GFP fluorescence was brighter for all CMVarI variants compared with the respective CMVarII variants (Figure 5). We next compared production of active $\mathrm{E} 1$ among the CMVarI and II E variants by immunoblotting (Additional file 7: Figure S7) and found that the reassortant wildtype CMVarI E gave more active E1 than did CMVarII E in side-by-side experiments (Table 3 and Additional file 7: Figure S7). By contrast, 


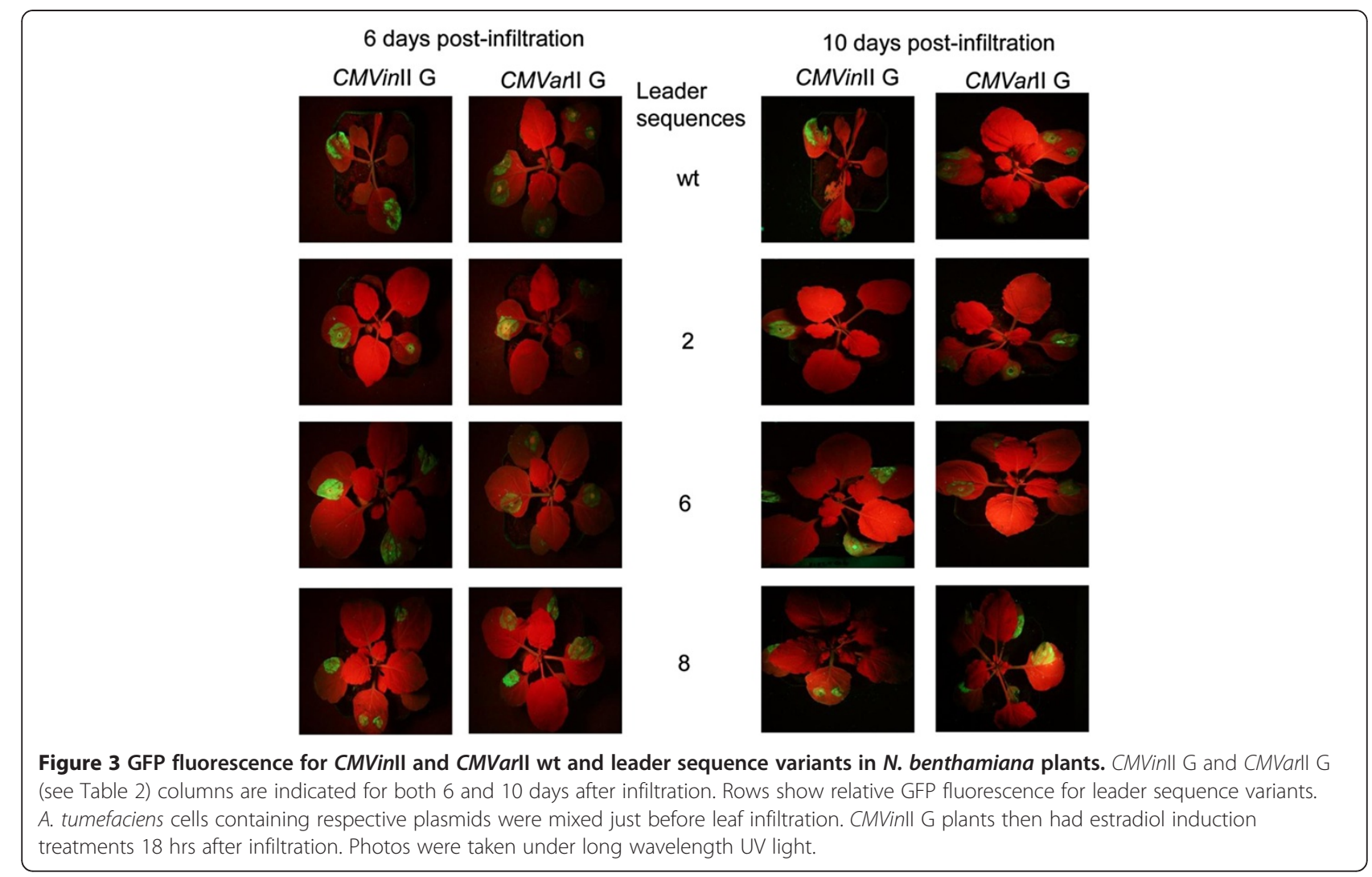

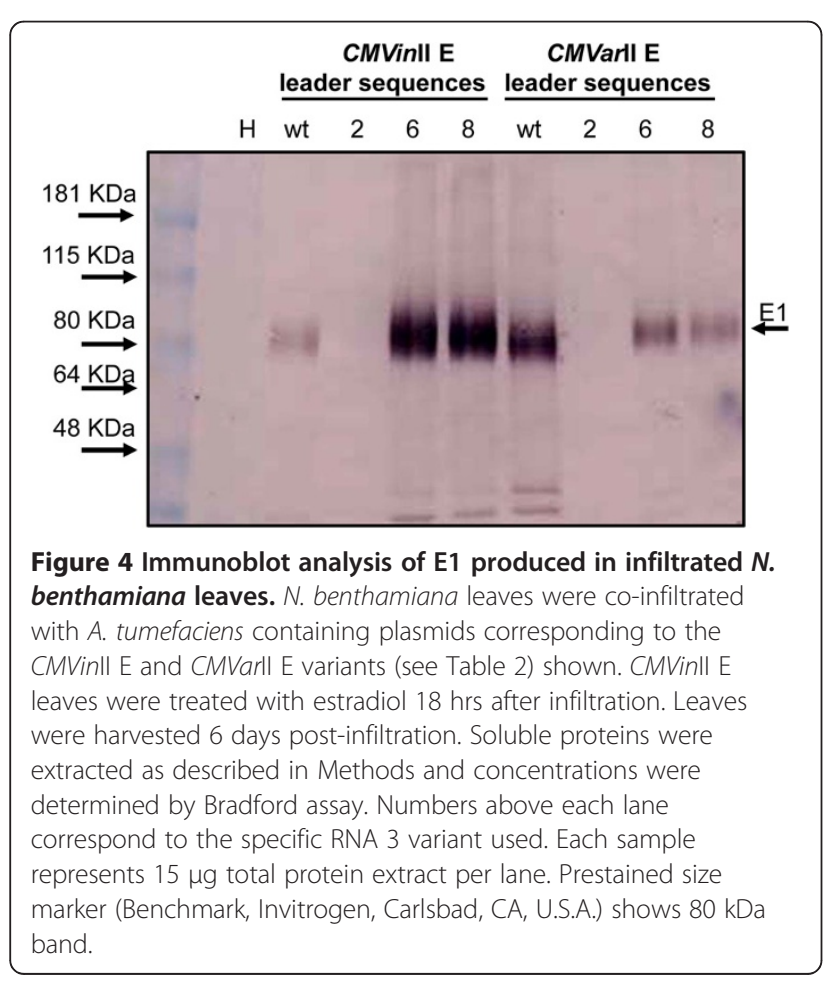

Table 3 Amount of active E1 ( $\mu \mathrm{g} / \mathrm{g}$ FW) in infiltrated $\mathbf{N}$. benthamiana leaves using the different CMVin and CMVar leader sequence variants

\begin{tabular}{|c|c|c|c|c|}
\hline & $-w t$ & -2 & -6 & -8 \\
\hline \multirow[t]{3}{*}{ CMVinll E } & $1.09 \pm 0.20^{1 \mathrm{D}}$ & $-0.01 \pm 0.00^{\mathrm{D}}$ & $14.74 \pm 2.14^{\mathrm{A}}$ & $13.97 \pm 3.40^{\mathrm{A}}$ \\
\hline & $1.07 \pm 0.80^{\mathrm{E}}$ & $0.22 \pm 0.36^{\mathrm{E}}$ & $8.76 \pm 3.49^{B C}$ & $9.38 \pm 2.10^{B C}$ \\
\hline & $1.00 \pm 0.45^{D}$ & $0.76 \pm 0.11^{\mathrm{D}}$ & $10.05 \pm 1.28^{B}$ & $11.05 \pm 3.85^{\mathrm{B}}$ \\
\hline \multirow[t]{3}{*}{ CMVarll E } & $2.23 \pm 0.59^{\mathrm{CD}}$ & $0.00 \pm 0.01^{\mathrm{D}}$ & $0.10 \pm 0.08^{\mathrm{D}}$ & $-0.01 \pm 0.00^{\mathrm{D}}$ \\
\hline & $6.30 \pm 3.50^{C D}$ & $0.01 \pm 0.03^{\mathrm{E}}$ & $0.33 \pm 0.33^{E}$ & $0.05 \pm 0.12^{\mathrm{E}}$ \\
\hline & $10.78 \pm 3.63^{B C}$ & $-0.01 \pm 0.01^{\mathrm{D}}$ & $1.58 \pm 0.49^{\mathrm{D}}$ & $1.85 \pm 1.13^{\mathrm{D}}$ \\
\hline \multirow[t]{3}{*}{ CMVarl E } & $4.12 \pm 3.35^{\mathrm{CD}}$ & $0.00 \pm 0.01^{\mathrm{D}}$ & $0.67 \pm 0.36^{\mathrm{D}}$ & $-0.01 \pm 0.00^{\mathrm{D}}$ \\
\hline & $9.38 \pm 2.10^{\mathrm{AB}}$ & $0.00 \pm 0.01^{\mathrm{E}}$ & $0.57 \pm 0.45^{\mathrm{E}}$ & $0.38 \pm 0.79^{E}$ \\
\hline & $15.15 \pm 5.39^{\mathrm{AB}}$ & $0.39 \pm 0.30^{\mathrm{D}}$ & $1.88 \pm 0.32^{\mathrm{D}}$ & $1.28 \pm 0.53^{D}$ \\
\hline \multirow[t]{3}{*}{ CMVarll 33E } & $6.74 \pm 2.82^{B C}$ & $0.08 \pm 0.12^{\mathrm{D}}$ & $1.17 \pm 0.82^{\mathrm{D}}$ & $2.27 \pm 1.81^{\mathrm{D}}$ \\
\hline & $5.61 \pm 2.01^{\mathrm{CDE}}$ & ${ }^{E} 0.01 \pm 0.01^{E}$ & $1.87 \pm 0.64^{\mathrm{DE}}$ & $1.15 \pm 0.77^{\mathrm{DE}}$ \\
\hline & $14.06 \pm 2.71^{\mathrm{AB}}$ & $0.21 \pm 0.26^{\mathrm{D}}$ & $1.17 \pm 0.98^{C D}$ & $1.72 \pm 0.93^{C D}$ \\
\hline \multirow[t]{3}{*}{ CMVarl 33E } & $11.34 \pm 2.67^{\mathrm{AB}}$ & $1.42 \pm 0.33^{\mathrm{D}}$ & $2.26 \pm 0.36^{C D}$ & $1.31 \pm 0.81^{C D}$ \\
\hline & $19.60 \pm 4.56^{\mathrm{A}}$ & $1.49 \pm 0.14^{\mathrm{DE}}$ & $2.03 \pm 0.31^{C E}$ & $1.73 \pm 1.09^{\mathrm{DE}}$ \\
\hline & $20.99 \pm 5.18^{A}$ & $1.16 \pm 0.96^{\mathrm{D}}$ & $1.97 \pm 0.48^{\mathrm{D}}$ & $2.49 \pm 1.61^{D}$ \\
\hline
\end{tabular}

${ }^{1}$ Numbers indicate E1 production as $\mu \mathrm{g} / \mathrm{g}$ fresh weight. Average \pm standard deviations are shown. Samples were collected 6 days post-infiltration, using 3 plants, 2 leaves from each plant $(n=6)$ for each biological trial. Results for three different biological trials are shown for each test. The identities of variants tested are given in Table 2. Group superscript letters next to the numbers represent different statistical groups, means with the same letter are not significantly different by the Bonferroni (Dunn) $t$ test using the SAS 9.1 program. 

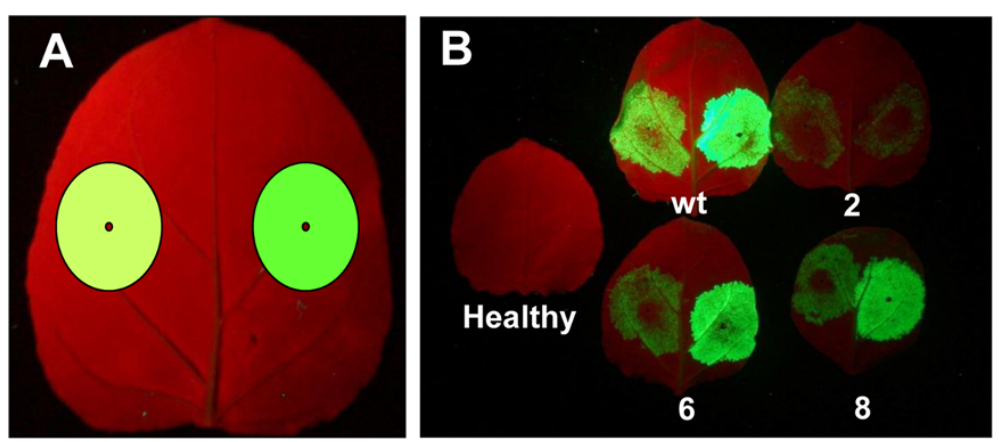

Figure 5 Comparison of GFP fluorescence from CMVarl G and CMVarll G variants. N. benthamiana leaves were co-infiltrated with A. tumefaciens containing plasmids corresponding to the CMVarl and II G variants (see Table 2) as shown at Panel A. Numbers for leaves in panel at right indicate specific RNA 3 variant. Photographs were taken 6 days post-infiltration under UV light shown as Panel B.

CMVarI E variants 2, 6 and 8 gave very low E1 accumulation. However, wildtype CMVarI E gave relatively high E1 accumulation, similar to that for CMVinII E variants 6 and 8.

\section{The MP C-terminal 33 amino acid deletion constructs showed increased yields compared to the intact MP constructs}

CMV requires both the $\mathrm{MP}$ and $\mathrm{CP}$ for cell-to-cell movement in plants, both of which are encoded by RNA 3 [5,26]. Thus for both CMVar and CMVin variants, when foreign sequences are cloned into the CP coding region, there is no cell-to-cell movement due to lack of the CMV-encoded CP, and the desired recombinant proteins (GFP or E1) accumulate only in the initiallyinfected cells. However, it was shown previously that when the CMV MP was mutated so as to lack the Cterminal 33 amino acids, CMV infections were able to move cell-to-cell in plants even in the absence of $\mathrm{CP}$ [27]. Therefore, we deleted the MP C-terminal 33 amino acids and compared E1 and GFP accumulation in plants using the CMVarI and CMVarII variants. GFP fluorescence was high for all variants with the 33 amino acid truncated MP (Figure 6). However, comparing E1 accumulation for all variants, the highest levels of active E1 were obtained for the 33 amino acid truncated CMVarI Ewt variant (Table 3). Our assays were for intact, enzymatically active E1, and we obtained yields up to $21 \mu \mathrm{g} / \mathrm{g}$ of active E1, corresponding to $\sim 0.4 \%$ of TSP. Furthermore, unlike for the wildtype MP variants, the CMVinII $33 \mathrm{E}$ variants 6 and 8 gave relatively low accumulation of E1.

\section{Discussion}

Several different viruses have been used for protein production in plants, and each has advantages as well as disadvantages [28-32]. Many of the "first generation" plant virus vectors $[28,33]$ utilized whole plant systemic virus infections to give desired proteins. While many of these have proven to be very useful there are some significant drawbacks. Systemic infections can take several days to fully develop. Protein production is then asynchronous and yields can vary in different tissues [3]. Recombinant viruses also show size constraints for the inserted sequence, often coding sequences of only $1 \mathrm{~kb}$ or less (encoding a protein of only $\sim 35 \mathrm{kDa}$ ) can be
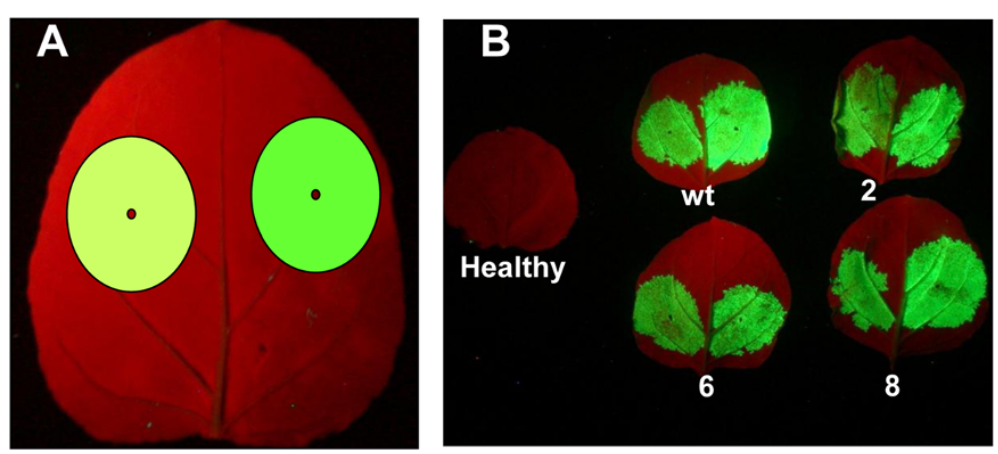

Figure 6 Comparison of GFP fluorescence CMVarl 33 G and CMVarll 33 G MP deletion mutants. N. benthamiana leaves were co-infiltrated with A. tumefaciens containing plasmids corresponding to the CMVarl and II $33 \mathrm{G}$ variants (see Table 2) as shown at left Panel A. Numbers for leaves in Panel $\mathbf{B}$ at right indicate specific RNA 3 variant containing MP deletion. Photographs were taken 6 days post-infiltration under UV light shown as Panel $\mathbf{B}$. 
inserted [34]. Then as the infection develops the viruses partially or completely excise the inserted recombinant sequence, leading to loss of the desired intact protein product $[28,35]$. Furthermore, some viruses (e.g. those with icosahedral capsids such as CMV) may have even more severe size constraints if RNA encapsidation is a requirement for development of the systemic infection. Then if the coding sequence for the desired protein is large, insertion into the viral RNA may preclude encapsidation, thereby preventing efficient spread.

Recent progress in developing Agrobacterium tumefaciens delivered plant virus-based protein production systems has been made by several research groups using different plant viruses $[31,34,36]$. These plant virusbased amplicon systems offer many advantages including the fact that non-transgenic plants can be used, the desired protein production is rapid, the product can accumulate to high levels, and virus-based expression can be temporally regulated to be almost synchronous in all infiltrated areas. Because a majority of the infiltrated cells become simultaneously infected, virus movement to new cells is not necessary, encapsidation of recombinant RNAs is not an issue. These "second generation" virus-based systems also can retain larger foreign coding sequences and thus produce larger proteins in plants [34], here we produced enzymatically active 56,000 MW E1.

In our previous work, we used the estradiol-inducible, CMV-based CMViva to produce $\alpha$ anti-trypsin (AAT) in non-transgenic $N$. benthamiana plants [9]. CMViva has all three CMV genome components in one large $28 \mathrm{kbp}$ plasmid, which, due to its large size is difficult to manipulate. Thus, here we took approaches to develop CMV-based inducible ( $C M V i n)$ as well as autonomously replicating (CMVar) systems, both of which are more easily manipulated and might be able to give high accumulation of heterologous proteins in plants. First, we separated the CMV genomic RNA cDNAs onto two plasmids, one containing the RNA 1 and 2 replicationassociated genome components and the other containing the CMV RNA 3 genome segment. The CMV RNA3 component is rather small in size, $2.2 \mathrm{~kb}$, and is easy to manipulate and to engineer to contain restriction enzyme sites to allow for easy removal of the CMV CP gene and replace it with any gene of interest. The desired restriction enzyme sites were introduced into the intergenic region of RNA 3. As expected, these altered the 5/ untranslated leader sequence of the resulting mRNA (RNA 4). The sgRNA promoter (for RNA 4 transcription) is within the minus strand of RNA 3 and is recognized by the RNA-dependent RNA polymerase and mRNA transcription is initiated. For CMV-Q RNA3, the transcription initiation starts at nt position 1167 in the intergenic region, which is upstream of the modified leader sequences. Our analyses demonstrated that the RNA 3 modifications affected RNA 3 and RNA 4 accumulation, but showed even more unpredictable effects on resulting protein accumulation. It does not appear that these can be attributed only to start codon context $[18,19]$ as the same construct (RNA 3) showed different protein yields whether the RNA was delivered using CMVin vs. CMVar.

In contrast to CMViva, both CMVinII and CMVarI and II variants require mixing $A$. tumefaciens cells containing different plasmids which are then co-infiltrated into plants and T-DNA from the different $A$. tumefaciens cells containing the CMV plasmids must be transferred to the same plant cell for the complete CMV amplicon. For CMVinII variants this is then followed by induction using estradiol, which resulted in high level accumulation of the proteins tested here (CP, GFP, E1). However, like for CMViva, the CMVinII RNA 1 deletion does not allow for its replication, only translation of the newly transcribed mRNA. Therefore we also developed the non-inducible autonomously replicating CMV-based system, CMVarI and II. Wildtype CMVar (expressing the CMV CP) replicated to very high levels and even caused systemic infections in plants. However, when genes for GFP or E1 were substituted for the CP gene, both proteins were produced in plants within the infiltrated areas, and quantitative analyses showed that high levels of proteins accumulated for both CMVin vs. CMVar, particularly at 6 days post-infiltration.

Although CMVinII E 6 and 8 variants gave slightly more active E1 in most experiments, CMVarI and II variants offers advantages in ease of use (e.g. no need to add the inducer) and thus, two additional approaches to improve accumulation of the desired protein product were investigated. Like most viruses having genomes composed of multiple segments, CMV genomic RNAs can be mixed (reassortment) to achieve genetic diversity $[37,38]$, and this offers opportunities for using CMV to produce desirable proteins in different plant species, as has been demonstrated also by others [3]. Therefore, we generated CMV reassortant genotypes by substituting CMV subgroup I genomic RNAs 1 and 2 derived from a more virulent $\mathrm{CMV}$, with the original CMV Q subgroup II RNA 3, giving CMVarI. Comparison of CMVarI and CMVarII G, E variants showed higher GFP and E1 for CMVarI G, E variants. However, the CMVarI Ewt showed higher E1 accumulation than did the corresponding CMVinII Ewt, but CMVinII E variants 6 and 8 gave the higher E1 accumulation than CMVar I 6 and 8 variants thus showing that reassortment alone was not sufficient.

As another alternative, we generated a MP C-terminal 33 amino acid deletion mutant. Cell-to-cell movement in CMV-infected plants requires interactions between 
the CP and MP [22]. Our CMV-based systems including CMViva, CMVarI and II and CMVinII are cell-to-cell movement deficient since they lack the $\mathrm{CP}$ and thus, desired recombinant proteins are produced only within infiltrated cells. However, previous workers demonstrated that the CMV MP C-terminal 33 amino acids are essential to recognize and interact with the $\mathrm{CP}$ [26]. When this region is deleted, the CMV infections can spread cell-to-cell even in the absence of CP [27]. In support of this the CMVarI and CMVarII $33 \mathrm{G}$ variants showed high CMV-based GFP production (Figure 6; and see [4]). When we created MP 33 amino acid deletion constructs and tested them, they showed increased production of not only GFP in CMVarI and II $33 \mathrm{G}$ variants, but also of E1 in CMVarI and II 33E variants (Table 3, Figures 5 and 6), and the highest yields of active E1 were obtained using the CMVarI 33E variants.

Other workers have produced versions of E1 in various transgenic plants with gene expression driven by different promoters. For example, full-length E1 containing the catalytic domain, linker and carbohydrate binding domain has been previously produced in transgenic tobacco plants. Based on the resulting E1 activity, yields of up to $0.25 \%$ on average of total leaf soluble proteins were shown with Mac promoter, a chimeric promoter of the CaMV 35S and mannopine synthase gene [11]. Similar yields were shown also with CaMV $35 \mathrm{~S}$ promoter [13]. In transgenic $Z$. mays seeds, the full-length E1 was produced using Glob-1 (Maize embryo-preferred globulin-1 promoter) and yields up to 6\% TSP were obtained [39]. In transgenic rice (Oryza sativa) plants, $35 \mathrm{~S}$ driven E1 lacking the carbohydrate binding domain but only containing the catalytic domain gave yields up to $4.9 \%$ TSP [40]. Thus, our yields of up to $0.4 \%$ TSP of intact E1 in nontransgenic $N$. benthamiana plants are similar to those achieved for intact E1 in transgenic tobacco, but less than those in more specialized systems. Furthermore, CMVin and CMVar-based production of the desired protein can be temporally regulated to give almost synchronous protein accumulation over a very short time period, even a few days.

\section{Conclusions}

Our data demonstrate that the CMV-based systems, CMVin and CMVar, are good candidates for production of desired heterologous proteins in nontransgenic plants. Our modifications described here, including manipulating cloning sites for foreign gene introduction, enhance the ease of their use, and reassortant genotypes and CMV movement protein deletions also allow for greater protein accumulation. Also, N. benthamiana, which is particularly suitable for agro infiltration, is a very good plant for protein production, but due to the wide host range of CMV, other plants may also prove to be useful for production of different proteins.

\section{Additional files}

\author{
Additional file 1: Figure S1. Construction of the pCMVar RNA 3 \\ plasmid.
}

Additional file 2: Figure S2. Northern blotting analyses of CMVin II variants.

Additional file 3: Figure S3. Construction of the pCMVar G and pCMVar E variants for GFP and E1.

Additional file 4: Figure S4. Construction of the pCMVar I and II for subgroup I, II RNA 1 \& 2 .

Additional file 5: Figure S5. Construction of the pCMVar $33 \mathrm{G}$ and pCMVar 33E for MP 33 amino acid deletion constructs.

Additional file 6: Figure S6. Systemic symptoms in plants for CMVar II variants.

Additional file 7: Figure S7. Immunoblot analysis of E1 produced in infiltrated $N$. benthamiana leaves for CMVar I E and CMVar II E variants.

\section{Abbreviations}

CMV: Cucumber mosaic virus; TMV: Tobacco mosaic virus; E1:

Acidothermus cellulolyticus endo-1, 4- $\beta$-glucanase; GFP: Green fluorescent protein; CP: Coat protein; ORF: Open reading frame; MP: Movement protein; FW: Fresh weight; TSP: Total soluble protein; RFP: Red fluorescent protein.

\section{Competing interests}

The authors declare that they have no competing interests.

\section{Authors' contributions}

MSH was responsible for experiment design, execution, analysis and wrote the manuscript. BEL was responsible for experimental execution including enzymatic activity assays and interpretation. KAM helped to conceive the study, discussed, and helped edit the manuscript. BWF helped to conceive the study, helped with organizing the experimental work, data interpretation, and helped to write and edit the manuscript. All authors read and approved the final manuscript.

\section{Acknowledgements}

We are extremely grateful to Dr. John Lindbo and to Dr. Mysore Sudarshana for many helpful discussions. We are especially grateful to Bill Adney, Senior Scientist at the National Renewable Energy Lab, for providing the E1 antibody. We also thank Dr. ShouWei Ding, University of California, Riverside, for the gift of pCassQ123. This work was supported in part by Chevron Technology Ventures, a division of Chevron, U.S.A., Inc; and NSF CBET-1067432

\section{Author details}

'Department of Plant Pathology, University of California, One Shields Avenue, Davis, CA 95616, USA. ²Department of Chemical Engineering and Materials Science, University of California, One Shields Avenue, Davis, CA 95616, USA ${ }^{3}$ Present address: Bayer HealthCare Pharmaceuticals, 800 Dwight Way, Berkeley, CA 94710, USA.

Received: 14 June 2012 Accepted: 11 September 2012 Published: 21 September 2012

\section{References}

1. Giddings $G$, Allison G, Brooks D, Carter A: Transgenic plants as factories for biopharmaceuticals. Nat Biotechnol 2000, 18:1151-1155.

2. Miele L: Plants as bioreactors for biopharmaceuticals: regulatory considerations. Trends Biotechnol 1997, 15:45-50.

3. Matsuo K, Hong JS, Tabayashi N, Ito A, Masuta C, Matsumura T: Development of Cucumber mosaic virus as a vector modifiable for different host species to produce therapeutic proteins. Planta 2007, 225 (5):277-286 
4. Fujiki M, Kaczmarczyk JF, Yusibov V, Rabindran S: Development of a new cucumber mosaic virus-based plant expression vector with truncated $3 a$ movement protein. Virology 2008, 381:136-142.

5. Palukaitis P, García-Arenal F: Cucumoviruses. Adv Virus Res 2003 62:241-323

6. Buck K: Comparison of the replication of positive-stranded RNA viruses of plants and animals. Adv Virus Res 1996, 47:159-251.

7. Lucy AP, Guo HS, Li WX, Ding SW: Suppression of post-transcriptiona gene silencing by a plant viral protein localized in the nucleus. EMBO J 2000, 19(7):1672-1680

8. Fukuzawa N, Ishihara T, Itchoda N, Tabayashi N, Kataoka C, Masuta C, Matsumura T: Risk-managed production of bioactive recombinant proteins using a novel plant virus vector with a helper plant to complement viral systemic movement. Plant Biotechnol J 2011, 9(1):38-49.

9. Sudarshana MR, Plesha MA, Uratsu SL, Falk BW, Dandekar AM, Huang TK, McDonald KA: A chemically inducible cucumber mosaic virus amplicon system for expression of heterologous proteins in plant tissues. Plant Biotechnol J 2006, 4:551-559.

10. Zuo J, Niu Q-W, Chua N-H: An estrogen receptor-based transactivator XVE mediates highly inducible gene expression in transgenic plants. The Plant Journal 2000, 24:265-273.

11. Dai Z, Hooker BS, Quesenberry RD, Thomas SR: Optimization of Acidothermus cellulyticus endoglucanase (E1) production in transgenic tobacco plants by trnascriptional, post-transcription and posttranslational modification. Transgenic Res 2005, 14:627-643.

12. Ransom C, Balan V, Biswas G, Dale B, Crockett E, Sticklen M: Heterologous Acidothermus cellulolyticus 1,4-beta-endoglucanase E1 produced within the corn biomass converts corn stover into glucose. Appl Biochem Biotechnol 2007, 137:207-219.

13. Ziegelhoffer T, Raasch J, Austin-Phillips S: Expression of Acidothermus cellulyticus E1 endo-beta-1,4-glucanase catalytic domain in transplastomic tobacco. Plant Biotechnol J 2009, 7:527-536.

14. Ding S-W, Rathjen JP, Li W-X, Swanson R, Healy H, Symons RH: Efficient infection from cDNA clones of cucumber mosaic cucumovirus RNAs in a new plasmid vector. J Gen Virol 1995, 76:459-464.

15. Xiang C: A mini binary vector series for plant transformation. Plant Mol Biol 1999, 40:711-717.

16. Lindenmuth BE, McDonald KA: Production and characterization of Acidothermus cellulyticus endoglucanase in Pichia pastoris. Protein Expr Purif 2011, 77:153-158.

17. Lin HX, Rubio L, Smythe A, Jiminez M, Falk BW: Genetic diversity and biological variation among California isolates of Cucumber mosaic virus. J Gen Virol 2003, 84:249-258.

18. Kozak M: Alternative ways to think about mRNA sequences and proteins that appear to promoter internal initiation of translation. Gene 2003, 318:1-23.

19. Kozak M: Regulation of translation via mRNA structure in prokaryotes and eukaryotes. Gene 2005, 361:13-37.

20. Nakamoto T: Evolution and the universality of the mechanism of initiation of protein synthesis. Gene 2009, 432(1-2):1-6.

21. Taliansky ME, Garcia-Arenal F: Role of cucumovirus capsid protein in long distance movement within the infected plant. J Virol 1995, 69:916-922.

22. Boccard F, Baulcomb D: Mutational anaysis of cis-acting sequences and gene function in RNA3 of cucumber mosaic virus. Virology 1993, 193:563-578.

23. Sakon J, Adney WS, Himmel ME, Thomas SR, Karplus PA: Crystal structure of thermostable family 5 endocellulase E1 from Acidothermus cellulolyticus in complex with cellotetraose. Biochemistry 1996, 35: 10648-10660.

24. Shi BJ, Palukaitis P, Symons RH: Differential virulence by strains of Cucumber mosaic virus is mediated by the $2 b$ gene. Mol Plant Microbe Interact 2002, 15:947-955

25. Du Z-Y, Chen F-F, Liao Q-S, Zhang H-R, Chen Y-F, Chen J-S: 2b ORFs encoded by subgroup IB strains of cucumber mosaic virus induce differential virulence on Nicotiana species. J Gen Virol 2007, 88:2596-2604.

26. Canto T, Prior DAM, Hellwald KH, Oparka KJ, Palukaitis P: Characterization of Cucumber mosaic virus IV. Movement protein and coat protein are both essential for cell-to-cell movement of Cucumber mosaic virus. Virology 1997, 237:237-248

27. Nagano H, Mise K, Furusawa I, Okuno T: Conversion in the requirement of coat protein in cell-to-cell movement mediated by the Cucumber mosaic virus movement protein. J Virol 2001, 75:8045-8053.
28. Choi IR, Stenger DC, Morris TJ, French R: A plant virus vector for systemic expression of foreign genes in cereals. Plant J 2000, 23:547-555.

29. Regnard GL, Halley-Stott RP, Tanzer FL, Hitzeroth II, Rybicki EP: High level protein expression in plants through the use of a novel autonomously replicating geminivirus shuttle vector. Plant Biotechnol J 2010, 8(1):38-46.

30. Jiang L, Li Q, Li M, Zhou Z, Wu L, Fan J, Zhang Q, Zhu H, Xu Z: A modified TMV-based vector facilitates the expression of longer foreign epitopes in tobacco. Vaccine 2006, 24(2):109-115.

31. Cañizares MC, Nicholson L, Lomonossoff GP: Use of viral vectors for vaccine production in plants. Immunol Cell Biol 2005, 83:263-270

32. Sainsbury F, Thuenemann EC, Lomonossoff GP: pEAQ: versatile expression vectors for easy and quick transient expression of heterologous proteins in plants. Plant Biotechnol J 2009, 7(7):682-693.

33. Gleba Y, Klimyuk V, Marillonnet S: Magnifection-a new platform for expressing recombinant vaccines in plants. Vaccine 2005, 23:2042-2048.

34. Gleba Y, Klimyuk V, Marillonnet S: Viral vectors for the expression of proteins in plants. Curr Opin Biothechnol 2007, 18:134-141.

35. Dawson WO, Lewandowski DJ, Hilf ME, Bubrick P, Raffo AJ, Shaw JJ, Grantham GL, Desjardins PR: A tobacco mosaic virus-hybrid expresses and loses an added gene. Virology 1989, 172:285-292.

36. Lindbo JA: TRBO: a high-efficiency Tobacco mosaic virus RNA-based overexpression vector. Plant Physiol 2007, 145:1232-1240.

37. Chen Y, Chen J, Zhang H, Tang X, Du Z: Molecular evidence and sequence analysis of a natural reassortant between cucumber mosaic virus subgroup IA and II strains. Virus Genes 2007, 35:405-413.

38. Boinnet J, Fraile A, Sacristán S, Malpica JM, García-Arenal F: Role of recombination in the evolution of natural populations of Cucumber mosaic virus, a tripartite RNA plant virus. Virology 2005, 332:359-368.

39. Hood EE: Subcellular targeting is a key condition for high-level accumulation of cellulase protein in transgenic maize seed. Plant Biotechnol J 2007, 5:709-719.

40. Oraby H, Venkatesh B, Dale B, Ahmad R, Ransom C, Oehmke J, Sticklen M: Enhanced conversion of plant biomass into glucose using transgenic rice-produced endoglucanase for cellulosic ethanol. Transgenic Res 2007, 16:739-749.

doi:10.1186/1472-6750-12-66

Cite this article as: Hwang et al:: Bipartite and tripartite Cucumber mosaic virus-based vectors for producing the Acidothermus cellulolyticus endo-1,4- $\beta$-glucanase and other proteins in non-transgenic plants. $B M C$ Biotechnology 2012 12:66.

\section{Submit your next manuscript to BioMed Central and take full advantage of:}

- Convenient online submission

- Thorough peer review

- No space constraints or color figure charges

- Immediate publication on acceptance

- Inclusion in PubMed, CAS, Scopus and Google Scholar

- Research which is freely available for redistribution 